\title{
Lithuania's Participation in International Peace Operations: Challenges of the NATO and EU Memberships
}

\begin{abstract}
In 2004, Lithuania celebrated not only its accession to the North Atlantic Treaty Organization (NATO) and the EU but also the tenth anniversary of its participation in international peace operations. In the last decade NATO became one of the key actors in resolving conflicts and crises in Europe; therefore, active participation of Lithuania in the operations of the Alliance contributed to its membership aspirations. However, it is not only NATO but also other international organizations that participate in the resolution of international conflicts in Europe as well as in the world; the EU is also building its crisis management force. The article analyses what challenges and problems Lithuania might encounter in executing its policy of international military participation already being a full member of NATO and the EU. Review of the expansion of international peace operations after the cold war and the development of NATO and the EU conflict and crisis management policy leads to the conclusion that the greatest challenges to Lithuania are caused by military aspects of peacekeeping and potential NATO and the EU competition.
\end{abstract}

\section{Introduction}

The year 2004 has become truly historic for foreign and security policy of Lithuania -it has successfully covered the way towards the set state objectives and joined the North Atlantic Treaty Organization (NATO) and the European Union (the EU) that should have to help guarantee the security of the country, establish the place of Lithuania on the map of the world and create premises for the prosperity of the country. One more anniversary celebrated by Lithuania is closely associated with these important changes ten years ago, on 22 August 1994, a peacekeeping platoon of the Lithuanian Army left on the first mission and participated in the United Nations (UN) operation in Croatia.

In the summer of 2004, approximately 200 Lithuanian military personnel already participated in six international missions in the Balkans, the Middle East, the TransCaucasus or Central Asia. The President of Lithuania Valdas Adamkus, congratulating military personnel with the tenth anniversary of their participation in international peace operations, stated that the contribution of the country to the enhancement of international security not only granted the possibility to strengthen its international prestige and

\footnotetext{
"Žaneta Ulozevičiùté is a lecturer of the Political Science Department of the Lithuanian Military Academy. Address: Šilo 5a, LT-10322 Vilnius, Lithuania tel. +370-5-2103569,

e-mail: zju@takas.lt
} 
helped demonstrate that Lithuania is a reliable partner of Western states but also "beyond doubt speeded up Lithuania's membership in the North Atlantic Alliance". ${ }^{1}$

Lithuanian peacekeepers have had a chance to participate in several UN, the Organization for Security and Cooperation in Europe (OSCE) peace missions in the Balkans and the Trans-Caucasus. However, in the middle of the last decade, NATO became one of the key actors in resolving conflicts and crises in Europe. Since then, Lithuanian troops have participated in almost all NATO peacekeeping operations and in 1999, when the EU began to build its own reaction force, promised to contribute to the peace initiatives of the Union.

Lithuania, declaring that it is ready to be not only the "user" but also the "provider" of security, should be interested in invigorating its peacekeeping activity and thus strengthen its authority in NATO. And not only in the Alliance, but also in the EU which forms the military component of crisis management. Threats to security that have recently emerged in the world, such as terrorism, proliferation of weapons of mass destruction, inducement of ethnic, economic or social problems, instability in certain regions, preclude from thinking that opportunities for undertaking the regulation of international security problems would decrease.

On the contrary, the US-led intervention in Iraq and the post-war operation for the implementation of security and stability, that has received strong political and military support of Lithuania, testify to the fact that this might be neither an opportunity nor a possibility to choose, but a necessity predetermined by both defensive/security and political interests. Aren't these potential necessities going to become a decisive challenge for the diplomacy and the participation in peacekeeping operations policy of the state that is trying to move forward by raft made of not so strongly tied NATO and the EU logs. Finally, how well Lithuanian Armed Forces, that have so far made attempts to adjust to the increased post-cold war demand for military instruments as well as to the expansion of international military operations, having limited financial and administrative resources and undergoing a new reform, are prepared for such challenges.

\section{Expansion of Peace Operations After the Cold War}

After the cold war, when tension between the two hostile blocks disappeared and intensive local conflicts considerably increased, peacekeeping forces came to be more often used to contain and resolve them. However, not only the scope of peace operations increased but also their essence and the very use of military forces in resolving conflicts also considerably changed.

Peacekeeping concept was "invented" in 1956 by the Canadian Prime Minister Lester B. Pearson who, when solving the Suez Canal crisis, proposed to replace the forces of the involved countries by the contingent of the United Nations. ${ }^{2}$ During the years of the cold war, peacekeeping was mostly associated with the deployment of small, lightly armed forces in the zone of conflict where they had to separate the warring parties. This, the so-called first generation peace keeping, got established as

${ }^{1} \mathrm{BNS}$, President congratulated and rewarded Lithuanian military personnel participating in international operations, 19 August, 2004.

${ }^{2}$ Duffey T., "United Nations Peace-keeping in the Post-Cold War Era" in Jones C., Kennedy-Pipe C., eds., International Security in a Global Age: Securing the Twenty-first Century, London: Frank Cass, 2000, p. 120. 
an alternative to the coercive measures of the United Nations Security Council and eventually formed key principles of peace interventions. Such operations were mainly related to the United Nations, led by the Security Council and collectively as well as voluntarily financed by member states. Peacekeeping operations could only be built with the approval and cooperation of local governments. Such operations had to be politically and militarily neutral; besides, military forces participating in them could use force in self-defence only. ${ }^{3}$

However, after the cold war, it became increasingly clear that such peacekeeping concept was not effective because the very nature of international conflicts had dramatically changed. Rather frequently they are caused by ethnic discord and this determines their great potential "explosive power"; in a conflict hostile parties are often not state armies, but paramilitary forces or civilian armed formations whose internal discipline is usually not rigid; therefore, they are difficult to control and might be unpredictable. Victims or targets of such conflicts are frequently peaceful population or civilian persons; conflicts might force a great number of people to abandon their homes and can cause an influx of refugees fleeing abroad. It is not infrequent that during a conflict one can observe the collapse of the political system of a state or a region causing a power vacuum. ${ }^{4}$

Actors involved in the resolution of conflicts have also changed - a major role in them can be played by non-governmental organizations; after the cold war, quite a few states have also conducted unilateral peace operations. The United Nations previously dominant in peace keeping came to be overshadowed by regional security organizations or coalitions of states eager for action. Changes in the substantiation and motivation of peace operations can also be discerned-the previous motive of the threat to international security came to be treated more broadly - the term threat is applied to humanitarian disaster, mass violations of human rights or breaking of security agreements of previously warring parties. ${ }^{5}$

Thus conflicts became very complicated, multidimensional and this determined a different attitude to the very resolution of conflicts. It could comprise most diverse action measures - from preventive deployment and diplomacy to the use of military forces for carrying out various tasks: provision of humanitarian assistance, separation of warring parties, restoration of political power. ${ }^{6}$ This forced traditional peacekeeping mechanisms to change as well. Ideas were also voiced about the peacekeeping of the second and third generation.

The second generation of peacekeeping was born when geography of peace operations considerably expanded; the international impact of conflicts increased as well. Attempts were still made to retain impartiality and receive the approval of the conflicting states in such missions, but peacekeeping forces were assigned much wider functions than before. It was not infrequent that the aim of their actions was not only to maintain the existing situation but also to actively participate in resolving the conflict by peaceful means. They could use force not just for self-defence but also, for example, to secure convoys of humanitarian assistance.

As it is noted, it would be more accurate to call the third generation peacekeeping operations by the term peace enforcement operations since such missions hardly comply with the fundamental principles of traditional and second generation peace keeping: agreement of the conflicting parties to grant peacekeepers access, impartiality of the

\footnotetext{
${ }^{3}$ Ibidem, p. 121.

${ }^{4}$ Ibidem, p. 118

${ }^{5}$ Ibidem, p. 113

${ }^{6}$ Lynch D., "New thinking in conflict management" in Cottey A., Averre D., eds., New Security Challenges in Postcommunist Europe: Securing Europe's East, Manchester: Manchester UP, 2002, p.112.
} 
intervention and non-application of force. ${ }^{7}$ International community might resort to such measures if the parties involved in the conflict do not approve of the peacekeeping mission though it is necessary to guarantee security on a broader, international scale or, say, to handle an uncontrolled humanitarian situation. It should be pointed out that peace enforcement might be combined with other more traditional peacekeeping measures, such as economic sanctions, weapons embargo or humanitarian assistance operations.

The transformation of peacekeeping is also reflected in general definitions of modern peace operations provided by the Ministry of National Defence of Lithuania (see Table 1).

The presented definition of peace keeping is much wider providing not only for the separation of the conflicting parties; the coercive nature of peace enforcement is clearly emphasized and the definition of peace building implies a new role of peacekeeping forces that emerged in the resolution of international conflicts in a post-conflict situation. At the same time, the definitions clearly illustrate the diversity of tasks that military forces participating in conflict and crisis management might be assigned and what "multilateral, complex, multinational and multicultural"s peace operations became after the cold war.

In combining peace keeping with preventive diplomacy, humanitarian and political objectives, a civilian component, whether it were a civilian police force or employees of non-governmental organizations, or representatives of international organizations participating in conflict resolution, began to gain a considerable importance in these missions. Thus, on the one hand, military personnel, participating in peace keeping, had to adjust not only to the increased role of civilian officials in missions of military nature, but also to the necessary closer cooperation of these two components. On the other hand, in the concepts concerning the use of military force for keeping peace, military principles and issues of military needs came to be more and more dominant. ${ }^{9}$ From the military point of view, operations became increasingly complicated, they were often conducted in a very hostile and alien environment, more diverse military measures involving services of air and sea components came to be used. Such peace operations, particularly peace building, came very close to being a full-scale war.

Quite a few significant aspects of this transformation of peace operations were revealed in resolving conflicts that occurred in Europe, particularly in the Balkans, after the cold war. It was here that new roles of such regional organizations as NATO and the EU emerged and, alongside these organizations, Lithuania started to carry out its peace missions too.

\section{NATO and EU Peacekeeping Initiatives and Lithuania}

Conflicts that occurred in Europe after the cold war made the principle of security indivisibility prominent and encouraged key actors of the region to search for new forms to guarantee it. In 1991, in its new strategic concept NATO foresaw that it had to take measures to resolve crises affecting the security of its members and, if necessary, to start crises response operations. ${ }^{10}$ As the definition indicates (see Table 1 ), these are various measures outside the notion of collective defence (Article 5 of the North Atlantic

\footnotetext{
${ }^{7}$ Ibidem, p. 121.

${ }^{8}$ Duffey, (note 2) p. 123.

${ }^{9}$ Lynch, (note 6) p. 120.

${ }^{10}$ NATO, Crisis management: How did policy evolve?,

http://www.nato.int/issues/crisis_management/evolution.htm, 09102005.
} 


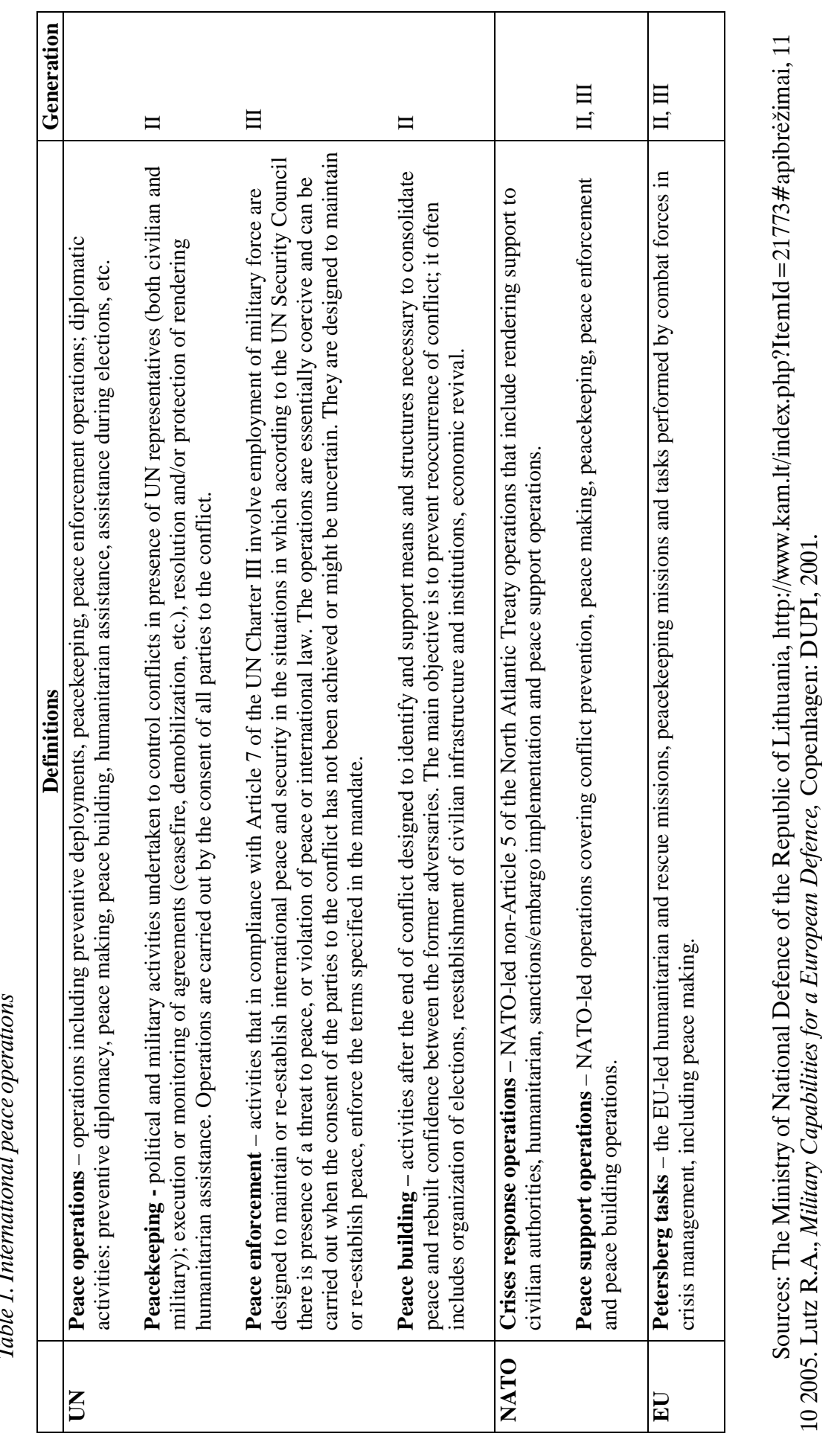


Treaty), including peace support operations that, in their turn, encompass peacekeeping missions of all generations. In the 1992 Maastricht Treaty, the EU also agreed to form a common foreign and security policy (CFSP). However, it failed to pass the first trial. Having no effective crisis management instruments, the EU was incapable of reaching a peaceful solution in the conflict that flared up in the collapsing Yugoslav Federation.

As it turned out, the United Nations, the main performer of peace operations in the world, was also not quite ready to fight conflicts based on ethnic issues. NATO supported the UN byvarious means: helping to guarantee economic sanctions and weapons embargo imposed on Yugoslav Republics, and monitoring non-fly zones. Quite a number of NATO members sent their military personnel to join the UN peace force UNPROFOR. With the help of one of NATO allies, Denmark, Lithuania also assigned a platoon to it.

However, these actions were not sufficient to stop the conflict in Bosnia. In the summer of 1995, NATO approved a military intervention to support peace efforts of the UN, including a two-week campaign of air strikes. After the Dayton Peace Agreement was signed, on the basis of the mandate granted by the Security Council of the UN, NATO began the first "non- Article 5" operation for the implementation of military aspects of the Dayton Agreement. ${ }^{11}$

In 1994, NATO began the Partnership for Peace Program (PfP), which helped the Alliance strengthen military relations with former communist adversaries and build preconditions for joint actions in seeking to guarantee security in Europe. Measures provided for in the Program not only encouraged states to participate in joint peace operations, but also granted the aspiring countries a possibility to come nearer to the membership in the Alliance. By establishing the Program and strengthening it in 1997, NATO clearly indicated that it pays great attention to real and potential participation of candidate states in peace missions.

Intensive conflicts and the following instability, uncontrolled organized crime, terrorism, trade in weapons, drugs or people, refugee-related humanitarian problems became evident as key threats in modern, hardly predictable world and, specifically, in Europe. Therefore, the Alliance, searching for new forms to substantiate its existence, began to regard the participation in the resolution of conflicts as one of the most significant tasks.

In the middle of the last decade, NATO turned out to be nearly the most effective structure from the existing ones in resolving conflicts frequently calling for military intervention. This was also proved by its 1999 decision to intervene, by using military measures, in the crisis in the province of Kosovo in Yugoslavia without a separate UN mandate, as well as the consequent mission in The Former Yugoslav Republic of Macedonia. In its Strategic Concept of 1999, NATO consolidated its role in resolving crises in Europe, while terrorist attacks of 11 September 2001 against the United States and the increased exposure to the threat of terrorism in the world prompted discussions about the possible role of NATO in resolving peace issues beyond Europe too. Since 2003, the geography of the Alliance's activity has expanded not only in speeches of officials and politicians.

${ }^{11}$ Ibidem. 
In August 2003, in Afghanistan, NATO took over the command of the UN designated International Security Assistance Force (ISAF), which guarantees security in the capital Kabul and several other provinces of the State; besides it has assumed responsibility for the security during the historical presidential elections held in the autumn of 2004..$^{12}$ Though NATO, as the Alliance, did not participate in the US-led military intervention in Iraq, it supplied assistance to its ally Poland that in Central Iraq commanded a multinational contingent responsible for safeguarding security in the post-war country. At the end of June 2004, when the sovereignty was returned to the interim government of Iraq, the Alliance began, at the latter's request, a mission of training and other technical support.

However, conflicts in the Balkans have already clearly shown that in spite of military structures and the reform of national armies after the cold war, many NATO European allies do not possess sufficient military capabilities required to guarantee the security of the Alliance members under modern realities. Attention, directed towards the state of European defence systems, prompted the members of the European Union to return to its malfunctioning common foreign and security policy.

Since it became clear that the block enjoying a great economic and political power cannot exert a full international power, if its diplomatic initiatives are not supported by intervention capabilities, the EU began to form a new common security and defence policy in the framework of existing of CFSP. In December 1999, during the summit in Helsinki, the EU decided to build autonomous institutional and military capabilities that would allow the EU to independently plan and execute military crisis management operations without NATO's participation. EU heads of state and government set the objective by 2003 to be ready to deploy in 60 days a 60 thousand strong rapid reaction force which, with the aim to dispel any apprehensions of the USA and other NATO allies in reference to the collective defence and duplication of NATO and the EU military component, were assigned to carry out the so-called Petersberg tasks primarily related to peace keeping, humanitarian and rescue missions.

However, European states do not hurry to carry out defence reforms or augment spending for military purposes; therefore, the strengthening of European defence capabilities encounters quite a few problems, the development of the EU rapid reaction force is going rather slowly. Part of the problems were solved when NATO and the EU agreement on the possibility to use military means of the Alliance, if the EU decided to undertake actions in a conflict without the participation of NATO, was eventually signed in 2003 after negotiations and debates that lasted more than a year. It paved the way for the EU to start its first peace mission when in March 2003, 350 troops replaced the NATO force serving in Macedonia. Likewise, in December 2004 the EU replaced the NATO peacekeeper contingent in Bosnia and Herzegovina. ${ }^{13}$

Since its first mission in Croatia within the UN force UNPROFOR, Lithuania has actively participated in peace operations in Europe, seeking to demonstrate its determination to contribute to the safeguarding of security on the continent. It was

\footnotetext{
${ }^{12}$ Hillier R., "Great Expectations", NATO Review 2, 2004. http://www.nato.int/docu/review/2004/ issue2/english/analysis2.html, 09102005.

${ }^{13}$ EU, Activities of the European Union: Foreign and Security Policy, http://europa.eu.int/pol/cfsp/overview_en.htm, 09092005.
} 
a means for a small country that had recently regained independence to establish its place in international politics, its diplomatic authority and at the same time a possibility to confirm its determination to carry out would-be NATO commitments.

Meanwhile, the awareness that the independence and security of Lithuania in the present-day world cannot be guaranteed by defending its territory only, because new threats can often be deterred beyond the borders of the State, gained stronger grounds ever in the strategic discourse. The Law on the Basics of National Security, adopted in 1996, already emphasizes that regional and global stability is an important interest of Lithuania; therefore, it is ready to contribute to its strengthening. In 2002 National Security Strategy, global and regional security is called the most important, primary interest of the State. Integration into NATO and participation in conflict prevention and crisis management operations, which is an inseparable part of it, are considered to be the main means to guarantee the security of Lithuania. ${ }^{14}$

Geography of Lithuania's participation in international peace operations is rather wide (see Table 2). With UN, OSCE, NATO and recently EU missions, Lithuanian troops participated in resolving conflicts in the Balkans. Representatives of Lithuania also contributed to OSCE peace missions in Trans-Caucasus and to international efforts to build peace in the Middle East as well as in Central Asia - Lithuanian troops serve in Afghanistan in ISAF and also in the US-led mission "Enduring Freedom". In Iraq, they help the US-led coalition to establish stability and democratic order after the regime of Saddam Hussein was overthrown.

It is important to note that, since Lithuania's participation in international missions over the decade, its contribution, regarding the population of Lithuania, has considerably increased. Besides, troops have to participate in missions of very different complexity, sometimes in a very hostile environment. Their specialization has also considerably expanded - not only conventional infantry contingents but also special task forces, military medics and logisticians are sent on missions.

\section{Challenges to the Army and Diplomatic Dilemmas}

With the shift to increasingly active and diverse participation in missions beyond the boundaries of the state after the accession to NATO and the EU, Lithuania started developing a small mobile army ready and equipped for expeditionary operations, at the same time refusing massive structures directed towards territorial defence.

Instead of previously planned three brigades, by 2008, Lithuania intends to form one reaction brigade with a command head-quarters, support and combat companies, two mechanized infantry battalions, two motorized infantry battalions and an artillery battalion. ${ }^{15}$ With the purpose of possible deployment for foreign missions, an infantry battalion is being formed in Rukla that will possess specialized capabilities for executing special purpose operations and tasks assigned to engineers and

\footnotetext{
${ }^{14}$ The Ministry of National Defence of the Republic of Lithuania, http://www.kam.lt/index.php?ItemId=9673, 09092004.

${ }^{15}$ Paulauskas K. "The Driving Logic Behind the Defence Reform in Lithuania: Building the Future Military”, Baltic Defence Review 1 (9), 2003, p. 133.
} 
military medics. To guarantee the flexibility of the army, its appropriate structure is being formed. According to the Army structure approved by the Seimas, by 2008, the professional component should be reinforced (in $2003-8,100$, in $2008-8,311$ military personnel), while the number of conscripts and the active reserve should be considerably reduced (from 4,500 to 2,000 and from 9,000 to 6,500, respectively, during the same period). ${ }^{16}$

Such army ready for NATO, EU or multinational expeditionary and crisis management missions dominated by professional service military personnel (or, in the future, consisting only of them) is not a cheep choice. The reform of the army itself will require considerable financial and other resources from Lithuania. However, it should not be forgotten that although NATO no longer is a clumsy military machine of the Cold War, the organization remains an alliance of collective defence. Lithuania that has been searching for an acceptable form of defence of the state since the restoration of independence can form an army directed towards reaction missions only because it is provided collective NATO security guarantees. Nonetheless, in order to make the guarantees on paper real (say, in the shape of NATO fighters guarding the Baltic airspace), there is a lot of work Lithuania has to do to be capable of taking the Alliance's support. The improvement of the infrastructure and the logistic system will also require a great deal of funds. One of the major challenges to Lithuania will be to coordinate its different military needs and find an optimal way to distribute its rather limited resources.

Resources also must be distributed adequately so that no differentiation, which might harm its overall efficiency, occurs in the army. Modern military forces must meet exceptionally high requirements. Within the country, for example, in the case of terrorist attacks, they must be ready to cooperate with civilian structures, police and, if need arises, they must be prepared to go on missions of different character and complexity, such as conflict prevention, crisis management, rescue or humanitarian ones. In post-conflict situations, they can play the role of a guarantor of stability and security as well as an assistant in the reconstruction of political processes in the societies, which are divided and not necessarily positively disposed. Such army needs perfectly trained military personnel not only in military terms, but also in linguistic capabilities, understanding public relations and diplomacy and at the same time ready to work using new information and military technologies. Such versatility and training requiring high qualifications in all areas proves to be costly and not easily attainable. It has been observed that in the armies of the former communist countries of Central and Eastern Europe, including Lithuania, units emerge whose training, equipment and "work quality" differ considerably from the rest. ${ }^{17}$

Allocation of considerable funds for international operations and training military personnel involved in them has so far proved to be more than the right thing - Lithuanian servicemen have often been perfectly assessed by heads and experts of foreign countries and armies; however, Lithuania will eventually have to address the problem how to prevent the differentiation of forces, one part being advanced, highly trained and experienced in international missions, and the other mostly dealing with conscripts. This might be rather difficult since, taking into consideration the political

\footnotetext{
${ }^{16}$ Ibidem.

${ }^{17}$ Edmunds T. "NATO and its New Members", Survival 3 (45), p. 17.
} 


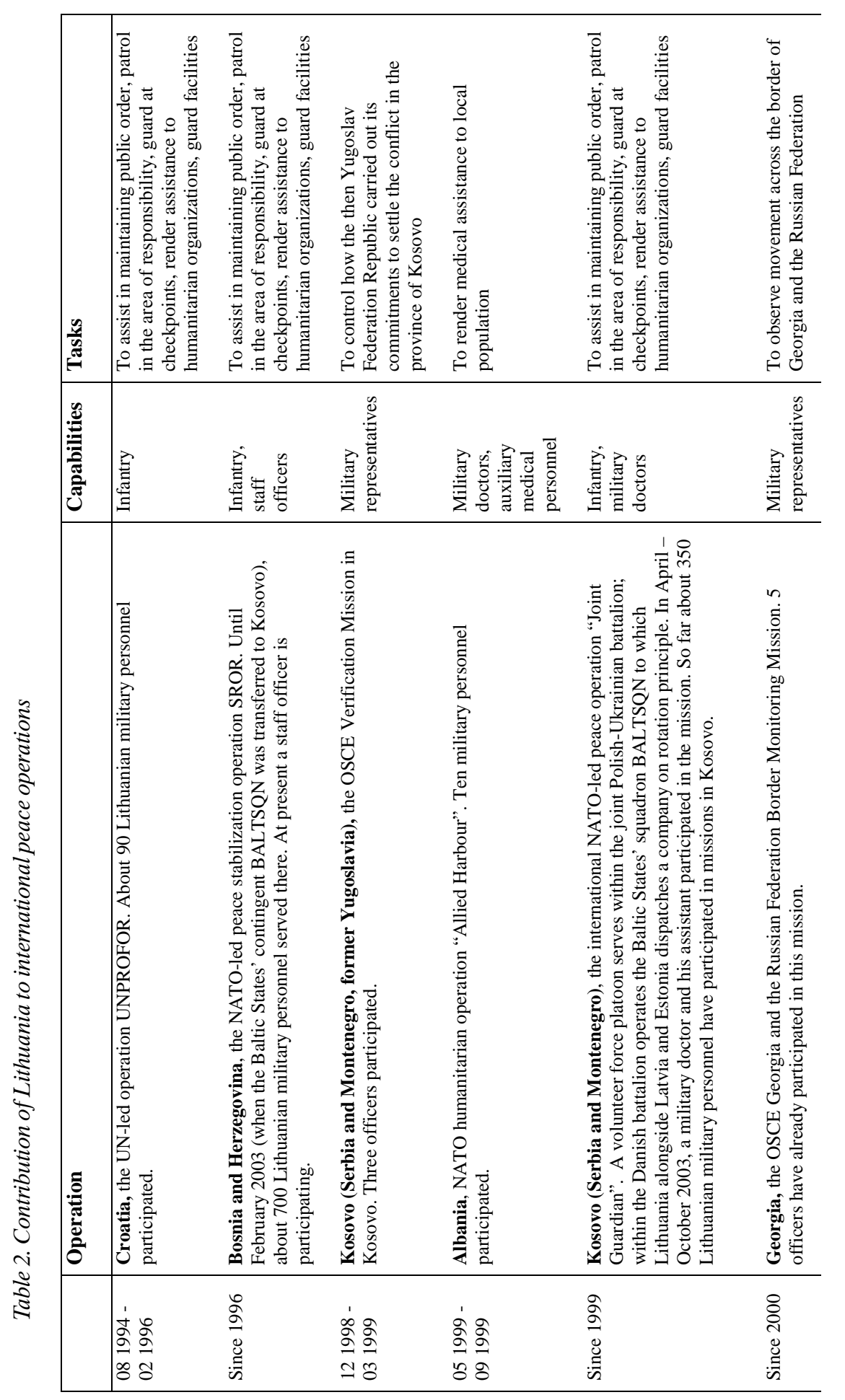




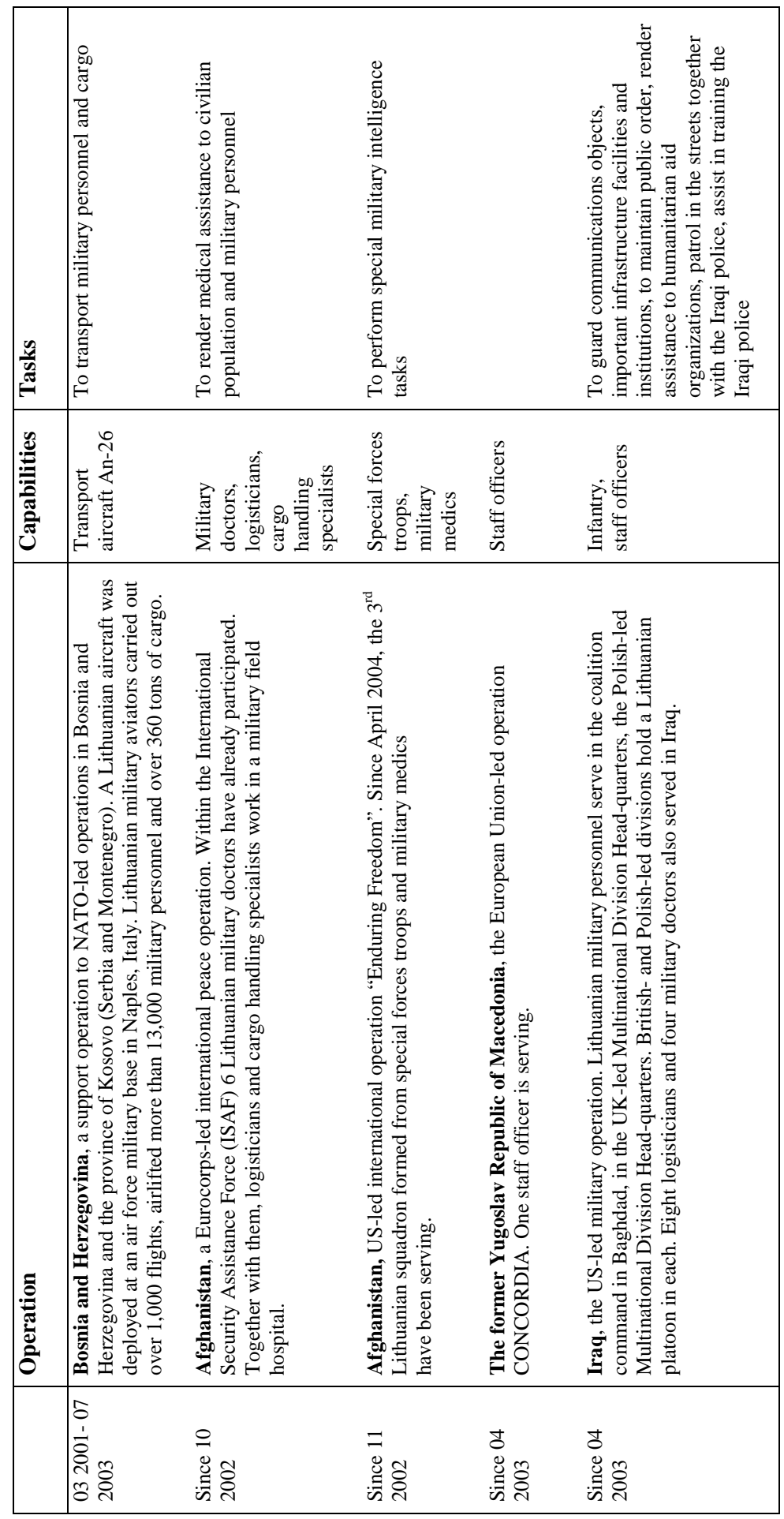

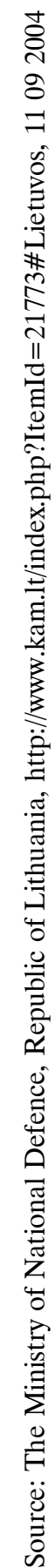


context, there is no indication of a decrease in the need to participate in international peace operations. On the contrary, one can predict that it will keep on increasing.

Lithuania sees the participation of its military personnel in international missions as a contribution to international security, and its assistance in NATO or EU missions, including military ones, is perceived as "an essential part of the membership". ${ }^{18}$ The country that has just joined NATO and the EU finds it also as a way of strengthening its situation and authority within these organizations and therefore it is concerned with its more active participation in different missions. Regarding the fact that by participation in resolving international conflicts both NATO and the EU seek to strengthen their international authority, these organizations are also concerned that the participation of their new members is very active. But Lithuania goes beyond the EU and NATO; its military personnel also take part in OSCE missions and in 2002 closer links with the UN were established - Lithuania assigned eight military medics and two ambulances to the Multinational Standby High Readiness Brigade (SHIRBRIG); so far they have not participated in UN missions. SHIRBRIG is part of the system of the UN Standby High Readiness Force. Military units attached to the brigade from different countries are deployed on their territories. After declaration of a mission, a brigade is formed which is sent to peace- keeping and humanitarian operations in any place of the world. The time of reaction of the brigade is from 14 to 30 days.

Lithuania's resources, however, are not inexhaustible. For example, as it has been announced, it was agreed to stop the mission of military aviators in a support operation within NATO-led operations in Bosnia and Herzegovina as well as in the province of Kosovo (former Yugoslavia, now Serbia and Montenegro) when the troops contingent in Iraq had to be increased..$^{19}$ Because of the lack of resources, it is inevitable that with the expansion of participation in some mission, participation in other missions will have to be stopped or limited; another alternative might be to distribute the available capabilities over a greater number of operations under way. However, such participation "everywhere and with everyone" without making a more considerable contribution might remain unnoticed and yield no desired diplomatic benefit. Lithuania has already faced this kind of paradox. For example, in June 2003, the Minister of National Defence Linas Linkevičius said that a record participation of Lithuania (13 military commitments and 7 international missions) demonstrates much more than a symbolic contribution to international security made by a country with the population of 3.5 million and 12,000-strong military forces. ${ }^{20}$ Nevertheless, in April 2003, presenting his assessment of the Baltic States' membership in NATO to the US Senate, Stephen Larrabee, a representative of the RAND Corporation, pointed to their political significance, though he was rather reserved about their military capabilities and called the contribution to the anti-terrorist operation in Afghanistan as more symbolic. ${ }^{21}$

\footnotetext{
${ }^{18}$ The Ministry of National Defence of the Republic of Lithuania, http://www.kam.lt/index.php?itemId=21773\#kodèl, 09102005.

${ }^{19}$ The Ministry of National Defence of the Republic of Lithuania, http://www.kam.lt/index.php?ItemId=21773\#Lietuvos, 09102005.

${ }^{20}$ Linkevičius L., "Life After Enlargement”, Baltic Defence Review 1(9), 2003, p. 106.

${ }^{21}$ Larrabee S. "The Baltic States and NATO Membership", Testimony presented to the United

States Senate Committee on Foreign Relations in April, 2003, p. 3.
} 
With regard to the fact that membership of NATO and the EU has so far been only something to strive for, foreign and security policy was directed towards several objectives - to demonstrate that Lithuania will be a reliable and active member of these organizations and, at the same time, to prepare its institutions and resources for the time when the membership will become a reality and it will be possible to use it "with full capability" for the implementation of the interests of the State. Having been engaged in preparation for membership in Euro-Atlantic structures, Lithuania did not formulate more specific directions of foreign and security policy apart from seeking to be a model member of the international community and contribute to strengthening NATO and the EU. However, in order to gain full diplomatic benefit out of limited recourses Lithuania can assign to NATO and the EU operations, more specific outline of international military participation policy, clear principles or even doctrine are necessary.

The issue of defining the directions that Lithuania would like to take in its foreign and security policy seems to be important also for the fact that both "political" and defence relations of NATO and the EU are far from being settled. A hint in the Treaty of the European Union about possible "collective defence" in case EU members decide upon it, strengthens the fears of competition between the EU and NATO expressed by the USA and some of its allies in Europe..$^{22}$ The division between NATO and EU defensive functions is usually argued by the fact that EU forces are assigned to execute only Petersberg tasks that are mainly associated with humanitarian and peacekeeping missions. However, taking a closer look at the concept of Petersberg Tasks (See Table 1), which emerged after WEU ministers met in Bonn in 1992, it is evident that there might be different interpretations. It does not clearly state which generation of peace keeping is meant there - the second, or maybe the third - peace building - once employment of military forces is provided for in crisis management and post-conflict situations in order to make peace. It is said that the concept of peace making, which is not given a more concrete explanation in the definitions of UN peace operations, was demanded to be included in the EU agreement by Germany, which kept a cautious position. However, there is no doubt that by it peace enforcement - undoubtedly actions of coercive nature - was meant. ${ }^{23}$ The EU does not have a unanimous position on the Petersberg Tasks, and opinions of its members on this issue vary. According to such countries as Britain or France, the 1999 operations in Kosovo or even the 1991 military actions in the Persian Gulf might undoubtedly be assigned to them, while other countries tend to considerably limit their scope.

It seems that the real ratio of NATO and EU defence dimension can be determined only by political self-determination. As follows from the aforementioned security and defence policy pursued by the EU, it is not likely that the EU could implement any major ambitions in conflict regulation. However, the trans-Atlantic tension that has mounted during recent years has impact on this area as well. European countries not approving of the USA policy and believing that they do not have enough opportunities to manifest themselves in the USA-dominant NATO seek to employ European foreign

${ }^{22}$ Heisbourg F., European Defence: Making it Work, Paris: ISS WEU, 2000, p. 6. (Chaillot paper 42).

${ }^{23}$ Ortega M., Military Intervention and the European Union, Paris: ISS WEU, 2001, p. 106.

(Chaillot paper 45). 
and security policy for the expression of their interests and opinion. Provided eventually these disagreements are not resolved and hot coals of the conflict keep smouldering threatening to flare up, Lithuania can face a diplomatic dilemma of strictly or at least more strictly choosing between NATO and the EU. Making a clear distinction between NATO as a collective defence alliance and the EU as rather an economic and political than defensive block, it has tried hard to avoid it. To Lithuania, that associates its security guarantees with NATO and its economic welfare with the EU, the perspective of this choice would be totally undesirable.

On the other hand, having become a full member of both organizations, Lithuania is granted a possibility to affect their relations. However, the country with a clearly pro-American position manoeuvring between dangerous undercurrents in the European Union where a great deal of important decisions are taken by the majority rather than by the principle of a unanimous vote can face a grave challenge. Its key task would be to factually prove that its foreign and security policy rests on two pillars - NATO and the EU - and a balance between commitments to present and future NATO and EU peace missions could contribute to that. Signs of this line of thinking are already visible in the current Lithuanian policy. In the spring 2004 Linas Linkevičius, who then was a defence minister, presented a rather lukewarm Lithuanian position on the initiative of EU battle groups and gave preference to NATO rapid reaction force..$^{24}$ In the NATO Summit held in Istanbul in June 2004, Lithuania announced about its intentions to increase its capabilities in the operations carried out (by NATO) in Afghanistan and the province of Kosovo in Yugoslavia. ${ }^{25}$ In November, however, Lithuania confirmed that it will be participation in one of the EU battle groups together with Poland, Germany, Slovakia, and Latvia, and, most likely, will assign a small logistics unit to it. ${ }^{26}$

\section{Conclusions}

Participation in resolving conflicts that flared up after the Cold War and, where the intervention of military force was rarely avoidable, offered Lithuania an opportunity to demonstrate its desire to be not only a user but also a provider of security. Over the decade, the considerably expanded geography of Lithuania's international military participation as well as the growing number of its peace keepers contributed to strengthening its international authority and thus bringing nearer the aspired membership of NATO. The aspiration and, at the same time, the need to be involved in different complexity peace operations requiring specific military capabilities and competence were among the factors in developing and later restructuring Lithuanian military forces. This aspiration was also reinforced by the fact that positions of both NATO and the EU, the other block that Lithuania sought to join, on participation in resolving conflicts, which were the cause of the main threats to the security of the continent and the world, underwent changes. After Lithuania became a full member of NATO and the

\footnotetext{
${ }^{24} \mathrm{BNS}$, Lithuania prepares its input into NATO rapid reaction force, will not scatter about the other initiatives, 12 February, 2004.

${ }^{25}$ BNS, Lithuania is planning to increase its capabilities in Afghanistan and Kosovo, defence minister says, 23 June, 2004.

${ }^{26}$ BNS, Lithuania will participate in creating EU rapid reaction battle groups, 22 November, 2004.
} 
EU, the main challenges to its participation in the policy of peace operations arise from military aspects of peace keeping and a potential competition between NATO and the EU. The country that so far has associated the safeguarding of its security with NATO and its economic development with the EU in the future will have to search for a Solomon's decision how to balance its limited military capabilities in order to meet the need to participate in peacekeeping initiatives of both organizations and how to make the optimum use of financial, administrative or other resources seeking to expand and improve military means necessary for international peace operations. 